Georgetown University Institutional Repository http://www.library.georgetown.edu/digitalgeorgetown

The author made this article openly available online. Please tell us how this access affects you. Your story matters.

Shore, Daniel. "Why Milton is Not an Iconoclast." PMLA 127:1 (2012): 22-37.

Collection Permanent Link: hdl.handle.net/10822/1041067

(C) 2012 Modern Language Association of America

This material is made available online with the permission of the author, and in accordance with publisher policies. No further reproduction or distribution of this copy is permitted by electronic transmission or any other means. 


\title{
Why Milton Is Not an Iconoclast
}

\author{
DANIEL SHORE
}

DANIEL SHORE is assistant professor of English at Georgetown University. His essays have appeared in Critical Inquiry, Milton Studies, and Milton Quarterly. This essay will be part of his book Milton and the Art of Rhetoric (Cambridge UP, forthcoming).
N THE CRITICISM OF THE PAST THIRTY YEARS THE TITLE ICONOCLAST has been appended to John Milton's name like a Homeric epithet: Hektor, "tamer of horses"; Agamemnon, "shepherd of the people"; Milton, "breaker of idols." John Guillory, an early adopter of the term, observed in 1983 that Milton is an "iconoclast, programmatically a breaker of images" (22). Critics have subsequently elevated the term to an overarching description of Milton's approach to theology, poetics, politics, and history. Lana Cable, for instance, writes of "Milton's literary iconoclasm": his "iconoclast impetus" and "iconoclastic instinct" produce "iconoclastic motifs" and "iconoclastic activity" (1). She calls iconoclasm "that most Miltonic yet analytically elusive trait" and describes her own project as an attempt to understand Milton's "iconoclastic poetics" (2). David Loewenstein refers to the poet of Paradise Lost as "Milton Iconoclastes" and argues that his works involve "breaking the image of the past," "casting down ... imaginations," and "shattering" the pretensions of his adversaries (62-64). Scholars often employ a substitute vocabulary to describe Milton's writings: instead of refuting idols he demolishes them; instead of criticizing images he breaks them; instead of a pen he wields a crowbar; instead of the written word, a sledgehammer. Metaphors of iconoclasm allow critics, much as they once allowed Milton, to trade the dry terminology of controversia for a language imbued with verve and force and to blur the line between literary debate and physical violence.

Critics who consider Milton an iconoclast are nevertheless among his most sensitive, and they envision him as no ordinary breaker of idols. Cable writes of "creative iconoclasm," which she defines as the dynamic interplay between destruction and creation (4-5). Loewenstein sees in Miltonic idol breaking a "regenerative"

(C) 2012 BY THE MODERN LANGUAGE ASSOCIATION OF AMERICA 
element that is intimately connected to "literary creativity" (147). In what follows, however, I argue that these critics labor under a shared misconception. Milton was not an iconoclast.

This misconception arises from two sources. First, although much of Milton's career is, as Achsah Guibbory puts it, "driven by an obsession with idolatry" (147), critics have wrongly assumed that such an obsession necessitates destruction. Their assumption has limited our recognition of the uniqueness and significance of Milton's opposition to idols and of his attempts to think beyond the preexisting cultural role of the iconoclast. Second, while Milton styles himself as an iconoclast at least once in his writings, critics have been too quick to take him at his word. Far from destroying idols, Milton seeks to capture and preserve them under judgment, investing them with poetic care even as he hollows them out from the inside, thereby refashioning them as the instruments of their own disenchantment. Milton's complex response to idolatry has much in common with the attempt "to suspend the urge to destroy images" and "to leave the hammer to rest" that the theorist Bruno Latour has dubbed "iconoclash" (15). Beginning with On the Morning of Christ's Nativity and ending with Samson Agonistes, my argument will follow Milton's efforts to develop and put into practice his alternative response to idolatry. At its most contentious, this essay will argue that even the tract Eikonoklastes (1649) is not an iconoclastic text. At its most speculative, it will propose that Milton's late poems gain much of their aesthetic power from the idols they preserve, through a kind of Lucretian experience that I call the "idolatrous sublime."

Because previous critics have employed iconoclasm broadly and often metaphorically, some clarification is in order. I take the term to have three relevant senses. The first is the literal destruction of images and objects. No one, to my knowledge, has argued that Milton ever put blade to canvas, hammer to stained- glass window, or fire to altar rail. The second sense involves recommending the removal or destruction of idols. Two of Milton's late tracts make this recommendation: Of Civil Power (1659) allows for magistrates to prohibit the "publick and scandalous use" of idols (255), while Of True Religion (1674) argues that popish idols and ceremonies should be removed from public and private spaces alike. A third sense will receive most of our attention. As a poet and polemicist, Milton writes about and against idols. For this reason the critics mentioned earlier have sought to expand iconoclasm to include the ways in which his texts challenge and refute other arguments, ideas, and texts. But it is precisely in the domain of the printed word, I will argue, that he practices an alternative response to idolatry, one that foregoes breaking.

England had been awash in iconoclasm for more than one hundred years when Milton began his polemical career. An injunction of 1538, issued under Henry VIII, had warned English clergy against "that most detestable sin of idolatry" and directed them to take down "such feigned images as you know ... to be so abused with pilgrimages or offerings" (Aston 227). Nine years later, during the reign of Edward VI, parish churches were ordered to "take away, utterly extinct and destroy" images, ceremonial objects, and "all other monument of feigned miracles, pilgrimages, idolatry, and superstition" (Aston 256). A new swell of iconoclasm was building as Milton composed his antiprelatical tracts in the early 1640 s. A parliamentary ordinance of 1643 called for "the utter demolishing, removing, and taking away of all Monuments of Superstition and Idolatry" and ordered that fixed altar rails and "all crucifixes, crosses \& all images of any one or more persons of the Trinity" be "taken away and defaced" (Ordinance). The commission to carry out these orders was given to William Dowsing, who over the next two years defaced or took away thousands of religious objects in 245 parishes across Cambridgeshire and Suffolk. 
Many of Milton's early polemical writings suggest that he took an active part in the culture of iconoclasm. He encourages his readers, in his Animadversions (1641), to "apply your sledges, your levers, and your iron crows to heave and hale your mighty Polyphem of Antiquity"; there he also threatens to "batter, and throw down your Nebuchadnezzars Image and crumble it like the chaffe of the Summer threshing floores" (700). In An Apology against a Pamphlet, published the following year, he imagines the martyrs who "rip up the wounds of Idolatry and Superstition with a laughing countenance" (903). But Milton's earliest mature poetry already presents a different response to the threat of idolatry.

On the Morning of Christ's Nativity, which Milton composed in 1629, when he was just twenty-one years old, depicts the triumph of an infant Christ over a throng of pagan deities. This triumph is not achieved through physical violence or destruction. The weapons of carnal warfare, the "spear and shield" (line 55), remain "idle ... high up hung" because the savior of mankind is able to "control" the gods of antiquity through his mere presence in the world $(55,228)$. On his arrival, Oracles grow "dumb," Apollo flees Delphos with a "hollow shriek," Peor and Baalim "forsake" their temples, and the Egyptian gods Isis, Osiris, and Anubis "haste" away $(173,178,198,212)$. There is evident and at times palpable aggression in Milton's descriptions. Thammuz has been "wounded" and Osiris feels "the dreaded infant's hand" (204, 222). And yet violence is directed only at the resident spirits of the "damnèd crew" (228). Even as the spirits flee, their idolatrous monuments are left behind unscathed. "Shrine" and "temples" $(176,198)$, "archèd roof" and "prophetic cell" $(175,180)$, "spring, and dale," "tangled thickets," "grove, or green," "urns, and altars" $(184,188,214,192)$-all these material objects remain, uninhabited but intact. Moloch, we are told, has "fled ... his burning idol" (205-07); the flame, however, is not an iconoclastic conflagration meant to incinerate the brass statue but a sacrificial blaze sparked by the idolaters for the immolation of children. The visible, material world remains unchanged at Christ's birth. The most dramatic physical transformation in the poem occurs when "chill marble seems to sweat" as it is abandoned by its resident power (195; my emphasis). And even this "sweat" is a lingering illusion, like the residue of a fitful dream.

The Nativity Ode describes in vivid detail what Max Weber calls the Entzauberung, or "disenchantment," of the world. Disenchantment does not cast down idols but rather leaves them void of spirit, value, and power. This is why the devotees of the pagan gods are described, in three instances, as worshipping the monuments of the banished deities "in vain" $(204,208,219)$, from the Latin vanus ("empty"). The infant Christ does not break the former objects of their veneration; he hollows them out from the inside, leaving behind only lifeless husks (Koerner 179).

Another early work, A Masque Presented at Ludlow Castle, imagines what it might mean to oppose idolatry without resorting to iconoclasm. The masque features two magical objects that are the source of Comus's power: a glass and a wand. Planning the rescue of the Lady from Comus and his "rabble," the Attendant Spirit directs her two brothers to "break his glass, / And shed the luscious liquor on the ground, / But seize his wand" (651-53). The brothers carry out the first of these commands successfully. Just as Comus lifts the glass to the lips of the Lady and enjoins her to "taste" (813), they "rush in with swords drawn, wrest his glass out of his hand, and break it against the ground" (91). But the Attendant Spirit scolds them for failing to carry out his second command:

What, have you let the false enchanter scape?

O ye mistook, ye should have snatched his wand

And bound him fast; without his rod reversed, 
And backward mutters of dissevering power, We cannot free the lady that sits here In stony fetters fixed, and motionless. ... .

The two magical objects correspond to two modes of opposition. The power of the glass evaporates with the physical integrity of the glass. This is the causal logic generally assumed by the iconoclast: if one wishes to put an end to idolatry, one must first put an end to the idol. But the wand suggests an alternative logic, in which the object that has wrought an enchantment may, when seized and "reversed," be used to disenchant. By this alternative logic, idols that reduce to servility also contain a "dissevering power" capable of freeing from "fetters." Because the brothers fail to bind Comus and snatch his wand, they must resort to the outside intervention of the nymph Sabrina, and the logic of capture and reversal remains unrealized. But this logic will be amply realized in Milton's later writings, in which captured idols become the instruments of dissevering power.

The case for an iconoclastic Milton rests most firmly on the prose tract Eikonoklastes. Written in 1649 to refute the popular Eikon Basilike, a book purportedly by the recently executed King Charles I, Milton chose to title his tract-and by extension himself"Iconoclastes, the famous Surname of many Greek Emperors, who in thir zeal to the command of God, after long tradition of Idolatry in the Church, took courage, and broke all superstitious Images to peeces." An iconoclastic response to the image of the dead king is needed, Milton claims, because "the People, exorbitant and excessive in all thir motions, are prone ofttimes not to a religious onely, but to a civil kinde of Idolatry in idolizing thir Kings" (343). ${ }^{2}$ But despite its title, and despite these claims, Eikonoklastes is not an iconoclastic tract.

To see why, we must consider the constraints of controversial writing, which nec- essarily limit the iconoclastic impulse. A hammer might pulverize an idol, reducing it to dust, but writing cannot defeat idols without reproducing them. All controversia must, to varying degrees, rebut and perpetuate, debunk and preserve what it opposes. The part of the oration rhetoricians called refutatio requires one to quote, summarize, or at least point back to the arguments one intends to refute. We might think of all controversial writing as operating on a spectrum.

On the low end of the spectrum is writing that attempts to hush even the echoes of the voices it contests. I include at this end the writing of early church fathers who, in seeking to wipe heresies out of existence, reluctantly preserve skeletal accounts of heretical doctrine. Every heresimach must, in effect, engage in heresiography. As historians of religion often point out, our knowledge of many heresies (including those, like Arianism, that may have influenced Milton) depends less on the intact writings of heresiarchs than on the partial remains passed down by the creators and defenders of orthodoxy (Lieb 263-64).

On the high end of the spectrum, controversial writing faithfully reproduces and disseminates the arguments it aims to refute. At its extreme, such writing recites these arguments in full or simply reproduces the contested text in toto. Here we might think of Lorenzo Valla, who quotes large swaths of The Donation of Constantine even as he demonstrates its spuriousness using the tools of philology.

Eikonoklastes stands at the high end of the spectrum, reprinting a large proportion of the words it wishes to refute. Indeed, the entire structure of Milton's argument is dictated by Eikon Basilike, which it follows chapter by chapter and even sentence by sentence. If we did not have myriad copies of the king's book-if they had all been destroyed by antiroyalists following the death of Charles I-it would nevertheless be possible to reconstruct the book from Milton's tract. Far from breaking all superstitious images and arguments to 
pieces, the tract preserves them as the objects of discrediting judgment.

Loewenstein speaks of Eikonoklastes as Milton's "most vehement polemic," in which he "demolishes, with such unrelenting rancor and fury, the image and spectacle of royalty projected in Eikon Basilike" (143). Compare this with the description offered by Gordon Campbell and Thomas Corns in their recent biography: "Milton works through Eikon Basilike, translating its pieties into substantive claims, which in turn are relentlessly discredited by reference to common knowledge and plain sense" (225). If these two accounts (one ascribing "rancor" and "fury" to the text, the other "common knowledge" and "plain sense") seem to describe different documents, in some respects they do. Loewenstein deftly represents the tract's prefacesome eleven pages in the 1649 edition-using Milton's own vehemently iconoclastic language. Campbell and Corns capture Milton at work in the tract's other 246 pages, where he engages in the familiar activities of written debate: weighing and judging, uncovering and comparing, questioning and challenging.

If, as I contend, we are mistaken in seeing Eikonoklastes as an iconoclastic text (not least because of its title), the fault is Milton's. Put simply, Milton engages in criticism and then disguises it as iconoclasm. We should always be ready to compare Milton's selfrepresentation with his habits, the roles he assigns to himself with the deeds he performs. In the case of Eikonoklastes, the disparity is sharp. The tract opens by emphasizing violent breaking, only to spend the rest of its pages subjecting the arguments of the king's book to carefully considered criticism. Milton is not an iconoclast; he just plays one in his preface.

Why dramatize refutatio as idol breaking? First, adopting the role of iconoclast allows Milton to activate a forceful association. The title Eikonoklastes transforms the king's eikon, meaning "image" or "portraiture," into an object of excessive and heretical devotion.
Where there's an iconoclast, there's an idol to be broken. One of Milton's chief aims is to fuse the concepts of monarchy and idolatry into the single concept that he calls the "civil kinde of Idolatry" (Hardin 15). Second, the language of iconoclasm endows the often pedestrian task of textual refutation with verve and force. Milton closely follows the argumentative structure of Charles's book, but he uses the metaphor of iconoclasm to imbue an otherwise reactive text with active energy.

Two representative passages from the tract's 246 pages of refutatio suggest that an operation other than iconoclasm is at work:

But what good Man had not rather want any thing he most desir'd for the public good, then attain it by such unlawfull and irreligious meanes; as much as to say, Had not rather sit still and let his Country be Tyranniz'd, then that the people, finding no other remedie, should stand up like Men and demand thir Rights and Liberties. This is the artificialest peece of fineness to perswade men into slavery that the wit of Court could have invented.

He bids his Son Keep to the true principles of piety, vertue, and honour, and he shall never want a Kingdom. And I say, People of England, keep ye to those principles, and ye shall never want a King.

What we find here is properly called criticism. Milton breaks Eikon Basilike into separate phrases and sentences that he subjects to judgment, but his fragmentation of the text is, as I suggested earlier, a necessary condition of textual refutation. He does employ vehement irony, fierce vituperation, and the kind of prophetic zeal that he first defended in $A n$ Apology. But only insofar as Charles's words remain present, preserved in italics, can they serve as the objects of irony, vituperation, and zeal. Like the immobile lovers depicted on Keats's Grecian urn, never consummating a desire that never fades, Miltonic criticism perpetually debunks lies that perpetually mislead. Assertion and refutation are pre- 
served alongside each other, capturing on the printed page the dynamics of Interregnum controversy. The passages quoted above display a rhetorical form that is central to Milton's polemics - the preservation of an idol under discrediting judgment-which I will

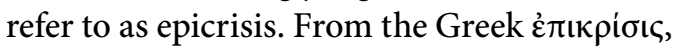
"to cast judgment on," epicrisis names the act of quoting a text and then offering commentary on it (Lanham 43).

The epicritical form repeated throughout Eikonoklastes is largely the product of the conditions of controversia: one must quote in order to refute. But Milton makes a virtue of this necessity in his late poems, which employ epicrisis even when the constraints of Interregnum debate are no longer operative. Consider, for example, the famous description of Mulciber's fall in the first book of Paradise Lost:

[A]nd how he fell

From Heav'n, they fabled, thrown by angry Jove

Sheer o'er the crystal battlements; from morn

To noon he fell, from noon to dewy eve,

A summer's day; and with the setting sun

Dropped from the zenith like a falling star,

On Lemnos th' Aegean isle: thus they relate,

Erring.

The form of this passage hews closely to that of Milton's prose refutations. Here too error is preserved under judgment, such that we might imagine all the words, with the exception of "they fabled" and "thus they relate, / Erring," printed in italics, as they were in the passages from Eikonoklastes. There are, however, some important differences. While Milton preserves the idolatrous myth of the past, he does so in his own words, not directly quoting the expressions of another. Judgment has receded to a curt if unambiguous retractio, allowing error a fuller and more continuous exhibition. Myth is not simply saved from oblivion, as polemical necessity would require; it is retold with a protracted, lingering pleasure that corresponds to the protracted length of Mulciber's fall, a "summer's day." In his controversial writings Milton extends to idols a provisional and pragmatic amnesty; in Paradise Lost he offers them a kind of poetic care. ${ }^{3}$ Epicritical form allows him to invest idols with the highest rhetorical and aesthetic appeal even as he subjects them to discrediting judgment.

Why would Milton have sought an alternative way of opposing idols? By the time he began his polemical career in the 1640 s, a century of iconoclasm had failed to eradicate idols from the English church (Aston 220). Previous efforts at casting down images had been sporadic and incomplete. Even in churches visited by iconoclasts, most images and objects managed to avoid destruction, while many parishes escaped violence altogether. Where icons were demolished, new ones sprang up in their place. The 1630s saw a particularly strong resurgence of images and ceremonial objects under the supervision of Archbishop William Laud, but there had been earlier periods of resurgence as well. Most obvious was the reign of the Catholic Queen Mary, but even under Elizabeth a proclamation issued against the "breaking or defacing of monumentes" intended "for memory, and not for superstition" had charged church governors to employ "sommes of money ... upon the spedy repayre or reedification of any such monuments so defaced or spoiled" (Proclamation). What is more, idols could effectively survive their own destruction through mechanical reproduction; the printing presses rapidly appearing throughout England in the seventeenth century allowed them to be massproduced (Eisenstein). Persons, objects, ideas, and arguments lived idolatrous afterlives on the printed page. It is telling that Milton spoke of King Charles I as an idol only after his execution, when his printed image was widely circulated in the front matter of Eikon Basilike.

Finally, even as idols were destroyed, the category of the idol expanded dramatically. At first idol referred primarily to images, 
to eikons, but by the 1640 s the term encompassed ceremonial objects like crosses, crucifixes, altar rails, fonts, and inscriptions. For some, like Milton, even persons, institutions, arguments, ideas, and ceremonies-anything that reduced men to servitude-could count as idols. Barbara Lewalski observes that "Milton's conception of idolatry was much broader and more far-reaching than that of his Puritan contemporaries," since he "insisted that anything could be made into an idol" (214). When anything can be made into an idol, the iconoclast must be prepared to break everything. Stained glass may be susceptible to the hammer, but what Francis Bacon called "the idols of the mind" are more elusive. As long as the inner propensity to idolatry remains, the outer destruction of material idols cannot fulfill its final end, at least not without tempting universal ruin. Milton sought an alternative means of combating idols not because of a principled opposition to violence, or because of secret iconophilia, or even out of some pluralist or tolerationist impulse, but because recent history had demonstrated iconoclasm's futility.

The catalog of fallen angels in the first book of Paradise Lost makes evident the futility of iconoclasm. In its inventory of "various names, / And various idols" drawn from the Old Testament and a range of other sources (Rosenblatt), the catalog traces the pattern of events whereby even God's chosen servants "fell / To idols foul" (1.374-75, 445-46). After recording the names of bestial Egyptian gods-"Osiris, Isis, Orus and their train"the passage recounts the tribe of Abraham's fall into animal worship as it journeyed to the promised land: "Nor did Israel scape / Th' infection when their borrowed gold composed / The calf in Oreb" $(1.478,482-84)$. The phrase "borrowed gold" looks back not only to Exodus 12.35-36 but also to Saint Augustine's famous analogy of pagan philosophy to Egyptian gold:

If those who are called philosophers, especially the Platonists, have said things which are indeed true and are well accommodated to our faith, they should not be feared; rather, what they have said should be taken from them as from unjust possessors and converted to our use. Just as the Egyptians had not only idols and grave burdens which the people of Israel detested and avoided, so also they had vases and ornaments of gold and silver and clothing which the Israelites took with them secretly when they fled, as if to put them to a better use.

$(2.40 .60)$

In Augustine's cheerful assessment, the intellectual achievements of an idolatrous civilization can, like raw materials, be profitably mined for the projects of Christian faith. Milton's gold has a darker sheen. The spoils of other cultures, as he tells it, carry with them an "infection" that prevents full and uncontaminated appropriation. Idolatry is not easily left behind, no matter how "detested and avoided." When melted down for new uses, "borrowed gold" ends up recapitulating its old function in a still more debased form; where the Egyptians had worshipped only the "monstrous shapes" of "gods disguised in brutish forms" (1.479-81), the Israelites "composed / The calf in Oreb" - that is, a brute pure and simple-for the object of their worship.

Iconoclasm can break individual idols, but it cannot eradicate the infection that gives rise to ever-changing forms of idolatry. Bruno Latour elaborates this predicament: "Why is it that all those destroyers of images ... have also generated such a fabulous population of new images, fresh icons, rejuvenated mediators: greater flows of media, more powerful ideas, stronger idols?" (15). Idolatry and iconoclasm succeed each other in a cycle of repression and return, in which every repression is more violent, every return more debased than the last. For Milton and other opponents of idolatry, this vicious cycle demanded a practical response.

In 1643 the official, state-sponsored response to iconoclasm's earlier failures was to broaden and systematize the project of 
destruction. At the behest of Parliament, William Dowsing treated the defacement of churches as an administrative undertaking to be carried out thoroughly and efficiently. "His first task in each church," writes John Morrill, "was to make an inventory of all objects of idolatry and superstition; his second was to destroy what he conveniently could and to leave orders for the destruction of the rest" (16). When time did not allow Dowsing or his assistants to demolish all the objects on his inventory, he would deputize local inhabitants to finish the job, occasionally returning to a parish multiple times to ensure that his instructions were successfully completed. Dowsing's journal, a record of his destructive itinerary through Cambridgeshire and Suffolk, vigilantly documents the objects he destroyed, ordered destroyed, or failed to destroy. Here is the writing of an iconoclast: "Jan. 5, 1643. At Linton, we took up 8 inscriptions, we beate downe 3 crucifixes, and 80 superstitious pictures, and brake the rayles, and gave order to deface 2 grave-stones, with Pray for our soules" (210). Dowsing's journal stands at the low end of the spectrum I introduced above: although it records the things he has defaced, it preserves only minimal traces of their existence. Devotional objects are listed and divided into categories, so that the last vestiges of their sensuous appeal are lost beneath the indifference of numbers. ${ }^{4}$

The first book of Paradise Lost offers a dramatically different way to "scape / Th' infection" of idolatry. Before cataloging the names by which the fallen angels were known on earth, Milton remarks that they had different names when they "erst in Heaven sat on thrones" (1.360). As a consequence of the fall, "of their names in Heav'nly records now / Be no memorial, blotted out and razed / By their rebellion from the Books of Life" (1.361-63; my emphasis). The phrase "blotted out and razed" is written in the language of iconoclasm, and, like Dowsing's journal, the "Books of Life" contain no memory of partic- ular idols, no record of their individuality or concreteness. But this scene lacks an iconoclast. Described in the passive voice as "blotted out and razed," the fallen angels erase themselves from history "[b]y their rebellion." As in the Nativity Ode, idols are successfully defeated without the ruinous intervention of an iconoclast. By rebelling against God, idols become their own best breakers.

The names of the angels in heaven are not "blotted out and razed" by God, or Milton, or Milton's poem. On the contrary, all three forces-divine, authorial, and textual-work to retrieve names, to recall and reinscribe them. Reinscription is, after all, the stated purpose of the catalog of demons: "Then were they known to men by various names / And various idols throughout the great world. / Say, Muse, their names then known, who first, who last" (1.374-76). Drawing on heavenly inspiration and the conventional gestures of epic anamnesis, Milton seeks to give idols a local habitation and a name, saving them from the oblivion they impose upon themselves. To short-circuit the vicious cycle of iconoclasm and iconophilia, idols are preserved as idols, held up to public view for continual criticism and judgment. The "borrowed gold" of Milton's Israelites becomes a threat when it is melted down to compose new creations, thereby losing the visible traces of its idolatrous origins. The catalog of demons, conversely, rescues idols from effacement and reconnects them with their origins. Unlike childish things, idols cannot simply be put away; they must be kept on public display as a record of their past infamy. Protestant churches in Reformation Germany sometimes housed a Götzenkammer, or "idol chamber," used to store ritual objects and pictures of saints that had been removed from view. The catalog of fallen angels-and indeed Paradise Lost itself-is a Götzenkammer thrown open as an exhibition hall.

Areopagitica articulates the central reasons for preserving and exhibiting idols. "[I]n 
the field of this world," Milton writes, good and evil "grow up together," leaving us with the "incessant labor to cull out, and sort asunder." Our chief intellectual vocation, by his account, is not the extirpation of error-it will always be with us because it arises from the "impurity" within us-but rather the arduous task of extricating from it the truth with which it is closely "involv'd and interwoven." The "true warfaring Christian" is not charged to dispose of idols, since this would merely put them out of sight and thereby render them still more insidious (514-15). As in Paradise Lost, error is understood as an "infection that may spread" (517). But this infection "cannot be supprest," Milton argues, likening the attempt to the actions of "that gallant man who thought to pound up the crows by shutting his Parkgate" (520). The solution lies neither in destroying the artifacts of error nor in removing them from view. To the contrary, once they have been culled from truth, they must be put on display, since "the knowledge and survay of vice is in this world so necessary to the constituting of human vertue, and the scanning of error to the confirmation of truth" (516). Like errors more generally, idols must be singled out, materially preserved, and made available for "survay" and "scanning." Milton effectively dismisses iconoclasts on practical grounds when he writes, "They are not skilfull considerers of human things, who imagin to remove sin by removing the matter of $\sin$ " (527). The objection is not that "removing the matter of sin" is wrong in principle, but rather that it is ineffective ("not skilfull"), since knowledge of the "matter of sin" is necessary to the "constituting of human vertue."

The form I have been referring to as epicrisis is the product of the strenuous "sort[ing] asunder" by which idols are culled from truth and held up to judgment. In Paradise Lost no idol is more carefully culled or unmistakably judged than Belial. Mentioned last in the catalog of "various idols" in the first book as the most "lewd" and "gross" of the demons (490-91), he delivers the most persuasive oration in the demonic council of the second book, arguing that the fallen angels should resign themselves to their place in hell:

Thus repulsed, our final hope

Is flat despair: we must exasperate

Th' almighty Victor to spend all his rage, And that must end us, that must be our cure, To be no more. Sad cure; for who would lose, Though full of pain, this intellectual being, Those thoughts that wander through eternity, To perish rather, swallowed up and lost In the wide womb of uncreated Night,

Devoid of sense and motion?

(2.142-51)

The appeal of this passage is founded on the theoretical ideal. "All men," writes Aristotle in the opening sentence of the Metaphysics, "naturally desire to know" (980a22), and Belial would have his demonic listeners believe the same of themselves. Like Aristotle's philosopher, their thoughts "wander through eternity," free from practical constraints (982a15). In language as ravishing as any in Milton's epic, Belial elevates speculative knowledge, divorced from obedience to God, to the position of supreme good.

The introduction to Belial's oration warns of its allure:

On th' other side up rose

Belial, in act more graceful and humane; A fairer person lost not Heav'n; he seemed For dignity composed and high exploit: But all was false and hollow; though his tongue Dropped manna, and could make the worse appear

The better reason, to perplex and dash Maturest counsels: for his thoughts were low; To vice industrious, but to nobler deeds Timorous and slothful: yet he pleased the ear, And with persuasive accent thus began....

$(2.108-18)$

Belial is condemned in no uncertain terms. The more false and devious his intent, the more effective his oratorical abilities are as 
instruments wielded for evil purposes. So powerful are Belial's counsels that the end of his speech is greeted with yet another round of narrative censure: "Thus Belial with words clothed in reason's garb / Counseled ignoble ease, and peaceful sloth, / Not peace ..." $(2.226-28)$. If he seems to have offered the path of facility and peace, we are cautioned that these decent goals are vitiated by ignobility and sloth.

For all their evident contempt, the narrative warnings do not mar the gorgeous surface of Belial's oration but rather attest to it. The most graceful and humane of the demons is given over a hundred lines of dazzling blank verse to state his arguments. The narrative warnings do not splinter these arguments or eliminate their force but render them "hollow" (2.112), much as the infant Christ hollowed out the dwellings of the pagan deities in the Nativity Ode. Readers are asked to apprehend at once the outer appeal of Belial's "persuasive accent" and its inner vanity. It is as if Dowsing, stumbling on a dilapidated stainedglass window in a parish church, had, instead of ordering its demolition, painstakingly filled each empty pane with deep stains of light and color, and then, after restoring it to a beauty beyond its original state, written beneath it these words: "thus they relate / Erring."

Loewenstein has argued that Milton remained an iconoclast through his "late" polemics, "right up until the Restoration and beyond," giving as evidence the following from Of Civil Power (1659): "the weapons of our warfare are ... mightie through God to the pulling down of strong holds; casting down imaginations and everie high thing that exalts it self against the knowledge of God ... having in a readiness to aveng all disobedience" (142). Itself a quotation from 2 Corinthians 10.3-6, this passage is written about iconoclasm. But to make the treatise into an endorsement of iconoclasm, Loewenstein elides the following phrase, italicized in the original- "the weapons of our warfare are not carnal; but mightie through God" (257) - and thereby obscures the distinction crucial to both the tract and Milton's broader response to idols. The passage is not advocating destructive violence; to the contrary, this quotation is taken from an extended argument repudiating "the force of this world." In matters of conscience, "spiritual power" is not only morally superior; it is also "allsufficient." Compared with this power, writes Milton, "how uneffectual and weak is outward force with all her boistrous tooles." Might we include among these tools not only the "idle spear and shield" of the Nativity Ode but also the "sledges," "levers," and "iron crows" of the iconoclast? Such tools violate the inverted hierarchy instituted by Christ, who "hath not chosen the force of this world to subdue conscience ... but rather conscience ... to subdue and regulate force."

Rejecting "carnal" weapons and "the force of this world" does not leave Milton without means of opposing idols. On the next page he quotes, from Matthew 23.23, Christ's reprimand to the Pharisees: "Ye have forc'd the conscience, which was not to be forc'd; but judgment and mercy ye have not executed: this ye should have done, and let the other alone." It is "judgment and mercy" that Milton "executes" with regard to Belial: mercy in granting him the most seductive arguments, judgment in declaring them "false and hollow." By executing judgment and mercy, he has forged the weapon of his spiritual warfare: an idol "reversed," turned back on itself as an instrument of "dissevering power."

It is with a feeling of regret, familiar by now to Miltonists, that I note an unavoidable exception to Milton's "judgment and mercy." Whereas OfCivil Power had opposed only the "publick and scandalous use" of idols (255), Of True Religion, Milton's final published prose tract, unequivocally recommends the removal of "Papist" idols from both public and private life: "Toleration is either public or private; and the exercise of their Religion, as 
far as it is Idolatrous, can be tolerated neither way: not publicly, without grievous and unsufferable scandal giv'n to all consciencious Beholders; not privately, without great offence to God, declar'd against all kind of Idolatry, though secret" (430-31). Having rejected the possibility of tolerating Catholicism, the tract advocates a return to the logic of the iconoclast: "first we must remove their Idolatry, and all the furniture thereof, whether Idols, or the Mass wherein they adore their God under Bread and Wine" (431-32). In this endorsement of iconoclasm we find neither the regenerative historical drama nor the dynamic process of destruction and creation that Loewenstein and Cable attribute to idol breaking. We find rather the banality of intolerance, the failure to extend, to Catholics as well as Protestants, the more principled opposition to idolatry articulated in earlier works and, indeed, in Of True Religion itself. Removing the "furniture" of idolatry is also, by Milton's own standards, a failure of practice. In proposing "to remove sin by removing the matter of sin," Milton allies himself with those he deemed in Areopagitica "not skilfull considerers of human things."

Other writings are more skillful. A Masque Presented at Ludlow Castle suggests the possibility of an alternative, noniconoclastic method of opposing idols; Eikonoklastes carries this method out in practice (if not in self-representation); Paradise Lost diagnoses the infection of idolatry and, by way of treatment, holds idols up to discrediting judgment. In the figure of Christ, Paradise Regained depicts the success of this treatment, showing how a perfect man may triumph over the most persuasive of idols without resorting to iconoclasm. Most of Milton's brief epic is given over to the arguments of Satan, who tempts Christ with various forms of worldly might. Christ immediately recognizes his interlocutor as the adversary who has set up "shrine[s]," "temples," and "oracles" as mouthpieces for the "deluding" rhetoric whereby the nations "fell / Idolatrous" (1.430-44). Satan also offers himself as an idol to Christ, promising "the kingdoms of the world ... / On this condition, if thou wilt fall down, / And worship me as thy superior lord" (4.163-67). Like his infant self in the Nativity Ode, the mature Christ does not raise his hand to topple shrines, temples, or oracles. The haunts of idols do not crumble. They merely fall silent, "mute" before the "living oracle" (1.459-60). Nor does Jesus silence altogether or "forbid" Satan from coming to ply him with idolatrous rhetoric (1.495). Rather, he hears him out, allowing the adversary to assert his claims in full before calmly and briefly rebutting them. With nearly all action and narration stripped away, the epicritical form characteristic of refutatio is more starkly manifest in Paradise Regained than in Milton's other poetry.

At only one point in the poem does the savior of mankind speak of violent, iconoclastic destruction. In the fourth book he prophesies that his future reign will be "as a stone that shall to pieces dash / All monarchies besides throughout the world" (4.149-50). Lewalski has noted that the image of the stone, drawn from Daniel 2.32-45, "seems to refer to [Christ's] millennial kingdom," which will come at an undetermined point in the future (226). Christ may be an eschatological iconoclast, but in the unfolding of human history he adopts a noniconoclastic response to idols. This response is illustrated by the different ways in which the image of the stone is recast throughout the poem. For instance, Satan's rhetorical forays are compared to "surging waves against a solid rock, / Though all to shivers dashed, the assault renew, / Vain battery, and in froth or bubbles end" (4.18-20). Before the advent of his millennial kingdom, this is how Christ chooses to thwart his adversary. The idols end up "all to shivers dashed" not because Christ assaults them but rather because they repeatedly renew their "assault" on him. Like the fallen angels in Paradise Lost, whose names were "blotted out 
and razed / By their rebellion," Satan acts as the instrument of his own destruction, while Christ triumphs by resisting the persuasive powers of the idols he repeatedly encounters.

In the complex and messy middle ground of human history, it is the image of the waves breaking against the rock, rather than the stone dashing "to pieces," that best captures Christ's final defeat of Satan. Placing Christ on the highest pinnacle of the Temple in Jerusalem, Satan challenges the Son of God to rely on a miracle to save himself from falling, observing that angels "shall uplift thee, lest at any time / Thou chance to dash thy foot against a stone" (4.558-59). But Satan finds that he has dashed himself against a stone when Jesus stands and responds, "Also it is written, / 'Tempt not the Lord thy God"' (4.560-61). At this reply, Satan is "smitten with amazement" and falls to earth. However these lines are read, it is clear that Christ's final triumph is not accomplished through destructive violence. ${ }^{6}$ Without needing to act, he stands "[p]roof against all temptation as a rock / Of adamant" (4.533-34; my emphasis). When man's obedience to God remains unshaken, iconoclasm proves superfluous as well as ineffective.

Paradise Regained does not depict an iconoclastic response to idols, but Samson Agonistes, published in the same volume in 1671, certainly does. Nowhere in Milton's works do we find a more spectacular act of destruction. At the poem's climax, Samson pulls down the theater of the Philistines and with it all the rituals, games, and ceremonies dedicated "to Dagon their sea-idol" (line 13). Critical debate has centered on whether Samson's suicidal iconoclasm is the act of a regenerate soul submitting to God's will or of a misguided enthusiast motivated only by his own inner promptings (Wittreich, Shifting Contexts 130). But we may put this question aside to inquire into the public consequences of his violent act rather than the personal impetus behind it. Following Samson's death, Manoa plans to memorialize his son with a monument:
[T]here will I

build him

A monument, and plant it round with shade Of laurel ever green, and branching palm, With all his trophies hung, and acts enrolled In copious legend, or sweet lyric song. Thither shall all the valiant youth resort, And from his memory inflame their breasts To matchless valor, and adventures high: The virgins also shall on feastful days Visit his tomb with flowers, only bewailing His lot unfortunate in nuptial choice, From whence captivity and loss of eyes.

(1733-44)

As Laura Lunger Knoppers has argued, "the supreme irony about the violence with which Samson Agonistes ends is that Samson's active iconoclasm against the Philistines enhances the tendencies toward idolatry in his own people" (61). I would add that violence does more than enhance "the tendencies toward idolatry"; it also leads to the construction of new idols. Manoa's monument amounts to a new object of worship in place of the Philistine idols destroyed with the theater. Again the symptoms of idolatrous "infection" present themselves: iconoclastic destruction gives rise to uncritical devotion to objects, succeeded in turn by new acts of "matchless valor." As I noted earlier, Milton's conception of idols extends well beyond images and ceremonial objects to include people, actions, and ideas-in short, the fullest range of persuasive human errors. In Manoa's vision we see the scope of idolatry extended further still: the memorial he plans to build in "monument," "legend," and "song" shows how Samson's final acts will themselves become the objects of idolatrous regard. For Milton, even idol breaking may insidiously come to serve as an idol.

Iconoclastic readings of Samson Agonistes dwell on the similarity between Samson's actions and Milton's beliefs (Loewenstein 140-51). Such readings understand the representation of iconoclasm as its endorsement. The reading I propose here seizes 
instead upon the difference between what Samson does as an iconoclast and what Milton does as a poet: where Samson pulls down through might, Milton preserves through verse. This reading understands the representation of iconoclasm as both an analysis of and an attempt to avoid iconoclasm's failure. By chronicling Samson's cataclysmic destruction of the Philistine idol and the substitute idol erected in celebration, Milton's tragedy leaves the hammer to rest, refusing to repeat once more the cycle of iconoclastic repression and idolatrous return.

I wrote at the outset that the rescued idols that populate Milton's poetry produce an experience we may call the "idolatrous sublime." In his criticism of Paradise Lost Samuel Johnson famously observed, "The characteristick quality of his poem is sublimity. He sometimes descends to the elegant, but his element is the great. ... He can please when pleasure is required; but it is his peculiar power to astonish" (286). Subsequent critics have agreed, employing the term sublime primarily in the sense defined by Longinus, to denote an elevated or "grand" style (Ricks 22). But the structure of epicrisis, of idols captured and preserved under judgment, suggests that Milton's poetry gains much of its power from a philosophical sublime as well.

In the most famous passage of De rerum natura, Lucretius writes of watching from a safe height the terror of mariners tossed on stormy seas below. This spectacle gives us delight, "not because any man's troubles are a delectable joy, but because to perceive what ills you are free from yourself is pleasant" (2.4-6). A still greater pleasure is available to those who, possessing "lofty sanctuaries serene, well fortified by the teachings of the wise," are able to "look down upon others and behold them all astray" (2.7-10). By observing turmoil from a secure vantage, we gain an awareness of our independence from affliction and the feeling of pleasure that arises from this awareness. Here delight is not, as it is elsewhere in Lucretius, the lure to instruction, the honey-rimmed cup that coaxes a child to drink bitter medicine (4.12-14); delight is rather the product of instruction, the joy that attends on our intellectual independence from ignorance and suffering. The experience described by these lines, at once educative and aesthetic, has sometimes been referred to as the Lucretian sublime.

In both Paradise Lost and De rerum natura the sublime is a difficult, elevated pleasure, the achievement of which requires one to look upon idols to realize one's independence from them. Two opposed forces are necessary to produce the experience of the sublime. In his account of the "dynamically sublime," Kant calls the first force Gewalt: an overwhelming power or subduing violence (260-61). For Lucretius, as for Kant, this force is epitomized by the storm-tossed sea, but in Milton's poetry it is the persuasive allure of the idol that threatens to reduce us to uncritical servitude. By rescuing and preserving such idols as Mulciber, Belial, and Satan at the height of their aesthetic and rhetorical appeal, Milton has placed behind this force the whole of his poetic care. The second force is a capacity for resistance. It carves out the secure vantage from which we can safely witness the overpowering threat of idolatry, preventing us from prostrating ourselves before even the most compelling idols. In a 1958 essay Geoffrey Hartman refers to this second force, which removes the reader to the position of "observer $a b$ extra" (6), as "Milton's Counterplot"-a plot, that is, counter to the fall of our first parents into sin and idolatry.

The two forces that produce the experience of the sublime correspond to the two parts of epicritical form. An idol is made available for scanning, but we are at least partly sheltered from its seductiveness by accompanying criticism. Epicrisis thus allows us to gaze upon overpowering idols without being overpowered. As in Lucretius and Kant, the idolatrous sublime results in more than 
aesthetic pleasure. Readers look upon idols without becoming enthralled and thereby rise to an awareness of their independence. Eminently "public" but no longer put to "scandalous use," idols themselves liberate readers from idolatry.

The idolatrous sublime furnishes us with an inverted account-a photonegative, as it were-of the formal features of Paradise Lost that Stanley Fish famously describes in Surprised by Sin as a "programme of reader harassment.” In Fish's account, reading the poem makes us repeatedly aware of our own fallen nature. After being carried away by the eloquence of Satan or Belial, we are brought up short by "a comment which complicates, and according to some, falsifies" our initial reaction to these seductive figures (4). It is this alternation of idolatrous seduction and corrective comment that I have described as epicrisis and that I take, as Fish does, to be a key feature of the epic. But the idolatrous sublime effectively overturns Fish's account of this experience: instead of discovering our fallen nature, we discover our independence from idols. The effect of our discovery is not, as Fish would have it, a sense of guilt or shame but rather a kind of rational exuberance. In the sublime experience of idols we find ourselves surprised not by sin but (to restore C. S. Lewis's title) by joy.

Earlier I likened Paradise Lost to a Götzenkammer, or Protestant "idol chamber," thrown open as an exhibition hall. This comparison locates Milton somewhere between the iconoclasts of the seventeenth century and the art collectors who rose to prominence in the eighteenth. Over the course of Milton's lifetime, northern European Protestants increasingly came to regard the material appurtenances of Catholic worship as "beautiful things" to be collected and cared for with secular rather than sacred adoration (Impey and MacGregor 147-59). Detached from their liturgical and devotional contexts and placed in Wunderkammern, salons, and exhibit halls, these objects were cut off from their religious purpose, rendered (in the terms of Kant's aesthetics) ohne Zweck ("without purpose"). But Milton's poems are not art museums. Reading Paradise Lost is hardly akin to strolling through a gallery, admiring relics of the past as harmless cultural treasures. Instead, the poem confronts us with dangers-enthralling orations, seductive errors, eloquent idolsthat require unceasing vigilance. The closest analogues are not the collections of the Louvre but rather, perversely enough, the museums of scientific atheism that Lenin set up in churches throughout the Soviet Union (Beemans; Blakeley). These museums displayed religious images and artifacts as dangerous instruments of ideological repression, not as objects of adulation. Composing Paradise Lost involved a bizarre kind of curatorial labor, an unusual kind of care. For Milton, as for Lenin, every exhibit is out to enslave us.

\section{NOTES}

1. The description of Milton as an iconoclast is pervasive and unchallenged: see Lewalski 213; Knoppers 8-9; Shoulson 231; Bryson 148; Sauer 164. Gilman addresses broader issues of iconoclasm in English Renaissance literature.

2. All quotations of Milton's Eikonoklastes are from The Complete Prose Works.

3. While I write of "amnesty," I am also partial to the metaphor Gregerson uses when she suggests that the similes of Paradise Lost constitute "a kind of house arrest for the likes of Homer, Virgil, and Ovid” (257). Despite describing Milton as an iconoclast, she claims that he and Spenser seek "to remedy idolatry by preserving and reforming the impulse they conceive to be idolatrous, not by fruitlessly seeking to eradicate it" (5). I argue, by contrast, that Milton preserves the idols themselves.

4. This essay benefited from James Simpson's conversation and generosity. For his account of Milton and Dowsing, which is contrary to my own, see 85-121.

5. See Hadfield on Milton's anti-Catholicism, which finds its most explicitly iconoclastic expression in Of True Religion but is present even in Areopagitica (565).

6. The essays collected in Wittreich's Calm of Mind and Rajan's The Prison and the Pinnacle contain a range of readings of these lines. 
7. Lucretius has for some time been acknowledged as a source for Milton's metaphysics, but scholars are beginning to see De rerum natura as a key influence on his aesthetics as well. See esp. Norbrook and Hardie on the Lucretian sublime.

\section{Works Cited}

Aristotle. Metaphysics. Trans. Hugh Trennedick. Cambridge: Harvard UP, 1969. Print.

Aston, Margaret. England's Iconoclasts, Volume 1: Laws against Images. Oxford: Oxford UP, 1988. Print.

Augustine. On Christian Doctrine. Trans. D. W. Robertson. New York: Liberal Arts, 1958. Print.

Beemans, Pierre J. "Scientific Atheism in the SovietUnion, 1917-1954." Studies in Soviet Thought 7.3 (1967): 234-42. JSTOR. Web. 16 Jan. 2010.

Blakeley, Thomas J. "Scientific Atheism: An Introduction." Studies in Soviet Thought 4.4 (1964): 277-95. JSTOR. Web. 16 Jan. 2010.

Bryson, Michael. The Tyranny of Heaven: Milton's Rejection of God as King. Newark: U of Delaware P, 2004. Print.

Cable, Lana. Carnal Rhetoric: Milton's Iconoclasm and the Poetics of Desire. Durham: Duke UP, 1995. Print.

Campbell, Gordon, and Thomas N. Corns. John Milton: Life, Work, and Thought. Oxford: Oxford UP, 2008. Print.

Dowsing, William. The Journal of William Dowsing: Iconoclasm in East Anglia during the English Civil War. Ed. Trevor Cooper. Woodbridge: Boydell, 2001. Print.

Eisenstein, Elizabeth. The Printing Revolution in Early Modern Europe. Cambridge: Cambridge UP, 1993. Print.

Fish, Stanley. Surprised by Sin. 2nd ed. Cambridge: Harvard UP, 1998. Print.

Gilman, Ernest B. Iconoclasm and English Poetry in the English Reformation. Chicago: U of Chicago P, 1986. Print.

Gregerson, Linda. The Reformation of the Subject: Spenser, Milton, and the English Protestant Epic. Cambridge: Cambridge UP, 1995. Print.

Guibbory, Achsah. Ceremony and Community from Herbert to Milton: Literature, Religion, and Cultural Conflict in Seventeenth-Century England. Cambridge: Cambridge UP, 1998. Print.

Guillory, John. Poetic Authority: Spenser, Milton, and Literary History. New York: Columbia UP, 1983. Print.

Hadfield, Andrew. "Milton and Catholicism." Milton and Toleration. Ed. Sharon Achenstein and Elizabeth Sauer. Oxford: Oxford UP, 2007. 186-202. Print.

Hardie, Philip. Lucretian Receptions: History, the Sublime, Knowledge. Cambridge: Cambridge UP, 2009. Print.

Hardin, Richard F. Civil Idolatry: Desacralizing and Monarchy in Spenser, Shakespeare, and Milton. Newark: U of Delaware P, 1992. Print.
Hartman, Geoffrey. “Milton's Counterplot.” English Literary History 25.1 (1958): 1-12. JSTOR. Web. 1 June 2010.

Impey, Oliver, and Arthur MacGregor, eds. The Origins of the Museum. Oxford: Clarendon, 1985. Print.

Johnson, Samuel. "Milton." The Lives of the Most Eminent English Poets; with Critical Observations on Their Works. Vol. 1. Ed. Roger Lonsdale. Oxford: Oxford UP, 2006. 242-95. Print.

Kant, Immanuel. Critique of the Power of Judgment. Ed. Paul Guyer. Trans. Guyer and Eric Matthews. Vol. 5. New York: Cambridge UP. 2000. Print.

Knoppers, Laura Lunger. Historicizing Milton: Spectacle, Power, and Poetry in Restoration England. Athens: U of Georgia P, 1994. Print.

Koerner, Joseph. “The Icon as Iconoclash.” Iconoclash. Ed. Bruno Latour. Cambridge: MIT P, 2002. 164-213. Print.

Lanham, Richard. A Handlist of Rhetorical Terms. 2nd ed. Berkeley: U of California P, 1991. Print.

Latour, Bruno. "What Is Iconoclash? Or Is There a World beyond the Image Wars?" Introduction. Iconoclash. Ed. Latour. Cambridge: MIT P, 2002. 14-37. Print.

Lewalski, Barbara. "Milton and Idolatry." SEL 43.1 (2003): 213-32. Print.

Lieb, Michael. Theological Milton: Deity, Discourse, and Heresy in the Miltonic Canon. Pittsburgh: Duquesne UP, 2006. Print.

Loewenstein, David. Milton and the Drama of History: Historical Vision, Iconoclasm, and the Literary Imagination. Cambridge: Cambridge UP, 1990. Print.

Lucretius. De rerum natura. Trans. W. H. D. Rouse. Cambridge: Harvard UP, 1992. Print.

Milton, John. Animadversions. Milton, Complete Prose Works 1: 653-735.

- An Apology against a Pamphlet. Milton, Complete Prose Works 1: 862-953.

- Areopagitica. Milton, Complete Prose Works 2: 480-570.

- The Complete Poetry and Essential Prose of John Milton. Ed. William Kerrigan, John Rumrich, and Stephen M. Fallon. New York: Random, 2007. Print.

- The Complete Prose Works of John Milton. Ed. Don M. Wolfe et al. 8 vols. New Haven: Yale UP, 1953-82. Print.

- Eikonoklastes. Milton, Complete Prose Works 3 335-601.

—_. Eikonoklastes: In Answer to a Book Intitl'd Eikōn Basilikē: The Portrature of His Sacred Majesty in His Solitudes and Sufferings. London, 1649. Early English Books Online. Web. 16 Jan. 2010.

- A Masque Presented at Ludlow Castle. Milton, Complete Poetry 61-98.

- Of Civil Power. Milton, Complete Prose Works 7: 229-73.

. Of True Religion. Milton, Complete Prose Works 8: $408-40$. 
On the Morning of Christ's Nativity. Milton, Complete Poetry 18-30.

—. Paradise Lost. Milton, Complete Poetry 251-630.

Paradise Regained. Milton, Complete Poetry 631-97.

The Reason of Church Government. Milton, Complete Prose Works 1: 736-861.

- Samson Agonistes. Milton, Complete Poetry 699-761.

Morrill, John. "William Dowsing and the Administration of Iconoclasm in the Puritan Revolution." Dowsing 1-28.

Norbrook, David. "Milton, Lucy Hutchinson, and the Lucretian Sublime." Tate Papers 13 (2010): n. pag. Web. 3 June 2010.

An Ordinance of Lords and Commons. London, 1643. Early English Books Online. Web. 16 Jan. 2010.

A Proclamation against Breaking. London, 1560. Early English Books Online. Web. 16 Jan. 2010.

Rajan, Balachandra, ed. The Prison and the Pinnacle. Toronto: $\mathrm{U}$ of Toronto $\mathrm{P}$ in assn. with $\mathrm{U}$ of Western Ontario, 1973. Print.

Ricks, Christopher. Milton's Grand Style. Oxford: Oxford UP, 1978. Print.
Rosenblatt, Jason P. “'Audacious Neighborhood': Idolatry in Paradise Lost, Book I.” Philological Quarterly 54.3 (1975): 553-68. Print.

Sauer, Elizabeth. Barbarous Dissonance and Images of Voice in Milton's Epics. Buffalo: McGill-Queen's UP, 1996. Print.

Shoulson, Jeffrey. Milton and the Rabbis: Hebraism, Hellenism, and Christianity. New York: Columbia UP, 2001. Print.

Simpson, James. Under the Hammer. Oxford: Oxford UP, 2010. Print.

Valla, Lorenzo. On the Donation of Constantine. Trans. G. W. Bowerstock. Cambridge: Harvard UP, 2007. Print.

Weber, Max. "Science as a Vocation." The Vocation Lectures. Trans. Rodney Livingstone. New York: Hackett, 2004. 1-31. Print.

Wittreich, Joseph Anthony, ed. Calm of Mind: Tercentenary Essays on Paradise Regained and Samson Agonistes in Honor of John S. Diekhoff. Cleveland: P of Case Western Reserve U, 1971. Print.

. Shifting Contexts: Reinterpreting Samson Agonistes. Pittsburgh: Duquesne UP, 2002. Print. 